\title{
GLUCO-LIPIDIC INDICES IN TREATED HYPOTHYROIDISM ASSOCIATED WITH NONALCOHOLIC FATTY LIVER DISEASE
}

\author{
Daniel Ferraz de Campos MAZO, Vicência Mara Rodrigues de LIMA, Jose Tadeu STEFANO, \\ Fabiola RABELO, Joel FAINTUCH and Claudia Pinto de OLIVEIRA
}

\begin{abstract}
Context - Thyroid hormones may interfere with regulation of lipid and carbohydrate metabolism as well as with severity of nonalcoholic fatty liver disease (NAFLD), however results are still debated. Objectives - Retrospective evaluation of clinical and metabolic correlations between hypothyroidism and NAFLD was the target. Methods - Clinical, biochemical and histological investigation of 103 NAFLD patients exhibiting drug-treated hypothyroidism was conducted. Results - Steatosis was present in $32.0 \%$ of the population and nonalcoholic steatohepatitis in $68.0 \%$. Females were the majority in both groups, with age of $50.0 \pm 1.5$ and $56.0 \pm 1.1$ years, respectively. Hypothyroidism was not rare $(15.5 \%)$, and multivariate analysis confirmed positive correlation with this disease for insulin ( $\mathrm{r}=0.213, P=0.03)$, glucose homeostasis index "HOMA" $(\mathrm{r}=0.221, P=0.02)$, aspartate aminotransferase $(\mathrm{r}=$ $0.234, P=0.01)$ and triglycerides above $150 \mathrm{mg} / \mathrm{dL}(\mathrm{r}=0.233, P=0.01)$. No association between hypothyroidism and steatohepatitis could be established. Conclusion - A link could be identified between hypothyroidism and markers of glucose and lipid homeostasis, but not with severity of NAFLD. The lack of correlation with liver biopsy requires further studies.
\end{abstract}

HEADINGS - Glycolipids. Fatty liver. Hypothyroidism.

\section{INTRODUCTION}

Nonalcoholic fatty liver disease (NAFLD) refers to a wide spectrum of liver damage, ranging from simple steatosis to nonalcoholic steatohepatitis (NASH), advanced fibrosis and cirrhosis ${ }^{(2)}$. NAFLD is closely related to the metabolic syndrome, a cluster of abnormalities including obesity (especially abdominal obesity), insulin resistance, impaired glucose metabolism, dyslipidemia and elevated blood pressure ${ }^{(18)}$. This relationship is becoming increasingly recognized, placing NAFLD as the hepatic representation of the metabolic syndrome ${ }^{(6,19)}$. Insulin resistance, oxidative stress and the inflammatory cascade are believed to play integral roles in the pathogenesis and progression of NAFLD ${ }^{(11)}$. The prevalence of hypothyroidism in patients with NASH is twice of that seen in controls $^{(12)}$, and this seems plausible, taking into consideration that the thyroid dysfunction can lead to hyperlipidemia, obesity and insulin resistance ${ }^{(15)}$, major components of the metabolic syndrome ${ }^{(9,20)}$, all of which are also implicated in the pathogenesis of NASH. Thyroid dysfunction is also associated with hepatic lipid peroxidation and oxidative stress in experimental models ${ }^{(3,16)}$, raising the question about the hypothyroidism role in NAFLD patients.
The aim of this study was to evaluate the frequency of hypothyroidism in NAFLD patients and to correlate presence of thyroid dysfunction with glucose homeostasis markers and liver damage in this population.

\section{METHODS}

This was retrospective clinical study with NAFLD patients followed in the Hepatology Outpatient Unit at Clinics Hospital of School of Medicine of the University of São Paulo, SP, Brazil. Patients were previously screened by means of hepatobiliary ultrasonography, viral serology, autoantibody titers, serum iron, ferritin and transferrin saturation, ceruloplasmin, copper levels and alpha 1-antitrypsin. Identification of metabolic syndrome components followed the recommendations of the Adult Treatment Panel III Report: fasting glucose $\geq 110 \mathrm{mg} / \mathrm{dL}$, triglyceride $\geq 150 \mathrm{mg} / \mathrm{dL}$, high density lipoprotein (HDL) $<40 \mathrm{mg} / \mathrm{dL}$ in men or $<50$ $\mathrm{mg} / \mathrm{dL}$ in women; and $\geq 130 \mathrm{~mm} \mathrm{Hg}$ systolic or $\geq 85$ $\mathrm{mm} \mathrm{Hg}$ diastolic pressure and abdominal obesity, given as waist circumference $>102 \mathrm{~cm}$ in men and $>88 \mathrm{~cm}$ in women ${ }^{(7,17)}$. Criteria for inclusion in this study were males and females patients $18-75$ years old with a histological diagnosis of NAFLD. Criteria for exclusion were any other acute or chronic liver or

University of São Paulo School of Medicine - Department of Gastroenterology (LIM-07), São Paulo, SP, Brazil.

Correspondence: Dr. Claudia Pinto Oliveira - Department of Gastroenterology, University of Sao Paulo School of Medicine - Avenida Dr. Arnaldo, $455,3^{\circ}$ andar, sala 3115 - 01246-903 - Sao Paulo, SP, Brazil. E-mail: cpm@usp.br 
biliary disease, substance abuse, especially alcohol intake of $>100 \mathrm{~g} /$ week, previous use of steatogenic medications (corticosteroids, methotrexate, amiodarone or tamoxifen) or refusal to participate in the investigation. All patients had biopsy proven NAFLD, and the liver specimens were scored by a single liver pathologist with expertise in NAFLD according to macro- and microvacuolar fatty change, zonal distribution, foci of necrosis, portal and perivenular fibrosis, and inflammatory and fibrotic infiltrate with zonal distribution. The slides were blindly classified according to the NASH activity score devised by the Pathology Committee of the NASH Clinical Research Network ${ }^{(10)}$. Fatty infiltration, which did not fulfill NASH criteria, was classified as steatosis only. Clinical and biochemical investigation included liver function tests were evaluated at the time of liver biopsy. Retrospective information of co-morbidities was collected as well.

Diagnosis of hypothyroidism was based on current therapy. Patients with diagnosis of hypothyroidism for more than 1 year and receiving synthetic T4 replacement were classified as affected. Subclinical hypothyroidism was not considered in this series. Insulin resistance was measured by the HOMA index, corresponding to the product of fasting plasma insulin concentration $(\mathrm{mIU} / \mathrm{L})$ and glucose concentration $(\mathrm{mmol} / \mathrm{L})$ divided by 22.5 .

All patients gave written informed consent, and this study was approved by the institutional Internal Review Board.

\section{Statistical analysis}

The SPSS version 13.0 (SPSS Inc., Chicago, Ill, USA) software package was used for statistical analysis. Groups were compared by Student's $t$ test, employing log conversion whenever appropriate. Linear regression analysis (Spearman) and logistic regression were conducted as appropriate. $P$ values of less than 0.05 were considered significant.

\section{RESULTS}

One hundred and three consecutive patients were eligible to be included in this study. All patients were negative for chronic viral liver disease, markers of Wilson's disease, hemochromatosis and autoimmune diseases and had current and past daily alcohol intake less than $100 \mathrm{~g} /$ week. The patients were divided into two groups: steatosis group ( $\mathrm{n}=$ $33 ; 32.0 \%)$ and NASH group $(\mathrm{n}=70 ; 68.0 \%)$, according to NAFLD Activity Score/NAS on liver biopsies. Demographics and selected clinical characteristics of each study groups are shown in Table 1.

In this population, $70 \%$ were females and the mean age was $50.0 \pm 1.5$ in the steatosis group and $56.0 \pm 1.1$ in the NASH group (Table 1). There were no statistical differences in age, gender or body weight between the groups. Statistically significant differences between steatosis and NASH group were found in the following parameters: fasting glucose, AST, GGT and HDL. The prevalence of hypothyroidism in this population of NAFLD patients was $15.5 \%(\mathrm{n}=16)$, being $15.2 \%(\mathrm{n}=5)$ in the steatosis group and $15.7 \%(\mathrm{n}=$ $11)$ in the NASH group. In multivariate analysis, insulin ( $\mathrm{r}$
TABLE 1. Clinical and biochemical differences between steatosis and NASH groups by the time of liver biopsy

\begin{tabular}{|c|c|c|c|}
\hline Variable & $\begin{array}{c}\text { Steatosis } \\
(\mathrm{n}=33)\end{array}$ & $\begin{array}{c}\text { NASH } \\
(\mathrm{n}=70)\end{array}$ & $P$ value \\
\hline Age (years) & $50 \pm 2$ & $56.0 \pm 1$ & 0.617 \\
\hline BMI $\left(\mathrm{kg} / \mathrm{m}^{2}\right)$ & $30.0 \pm 5.4$ & $31.7 \pm 5.2$ & 0.102 \\
\hline $\begin{array}{l}\text { Fasting glucose } \\
(\mathrm{mg} / \mathrm{dL})\end{array}$ & $118.5 \pm 59.8$ & $127.2 \pm 50.9$ & $0.016 *$ \\
\hline Insulin $(\mu \mathrm{U} / \mathrm{mL})$ & $19.8 \pm 22.7$ & $18.1 \pm 9.4$ & 0.185 \\
\hline HOMA index & $6.5 \pm 10.0$ & $6.1 \pm 5.9$ & 0.089 \\
\hline $\begin{array}{l}\text { Hemoglobin } \\
(\mathrm{g} / \mathrm{dL})\end{array}$ & $13.5 \pm 1.5$ & $14.2 \pm 1.5$ & 0.115 \\
\hline WBC $\left(/ \mathrm{mm}^{3}\right)$ & $7478 \pm 2156$ & $6.906 \pm 2.233$ & 0.228 \\
\hline AST (U/L) & $35.6 \pm 28.3$ & $44.3 \pm 38.8$ & $0.002 *$ \\
\hline $\operatorname{ALT}(\mathrm{U} / \mathrm{L})$ & $49.6 \pm 45.2$ & $60.0 \pm 41.9$ & 0.065 \\
\hline GGT (U/L) & $47.0 \pm 33.0$ & $121.6 \pm 169.4$ & $0.005 *$ \\
\hline $\begin{array}{l}\text { Total cholesterol } \\
(\mathrm{mg} / \mathrm{dL})\end{array}$ & $201.7 \pm 38.2$ & $192.8 \pm 45.5$ & 0.358 \\
\hline HDL (mg/dL) & $58.7 \pm 11.1$ & $50.8 \pm 14.2$ & $0.000 *$ \\
\hline LDL (mg/dL) & $124.5 \pm 46.0$ & $110.8 \pm 35.7$ & 0.295 \\
\hline $\begin{array}{l}\text { Triglycerides } \\
(\mathrm{mg} / \mathrm{dL})\end{array}$ & $176.0 \pm 95.2$ & $159.6 \pm 78.4$ & 0.395 \\
\hline
\end{tabular}

Groups were compared by Student's $t$ test, employing log conversion whenever appropriate NASH - nonalcoholic steatohepatitis; BMI - body mass index; AST - aspartate aminotransferase; ALT - alanine aminotransferase; GGT - gama glutamil transferase; HDL - high-density lipoprotein; HOMA - homeostatic model assessment; LDL - low-density lipoprotein; WBC - white blood cell

$=0.213 ; P=0.03)$, HOMA index $(\mathrm{r}=0.221 ; P=0.02)$ and AST $(\mathrm{r}=0.234 ; P=0.01)$ were correlated positively with hypothyroidism (Table 2). In addition, triglyceride levels $>150 \mathrm{mg} / \mathrm{dL}(\mathrm{r}=0.233 P=0.01)$ also showed correlation with hypothyroidism. However, a direct association between hypothyroidism and NASH could not be demonstrated. No correlation occurred between triglycerides and severity of NAFLD $(r=0.009$, NS).

TABLE 2. Correlation between hypothyroidism and metabolic markers in patients with NAFLD

\begin{tabular}{lcc}
\hline Variable & Correlation index ("r") & Significance \\
\hline Insulin & 0.213 & $P=0.03$ \\
HOMA index & 0.221 & $P=0.02$ \\
AST & 0.234 & $P=0.01$ \\
Triglycerides & 0.233 & $P=0.01$ \\
\hline
\end{tabular}

Spearman correlation confirmed by multivariate analysis

Only significant results are shown

HOMA - homeostatic model assessment; AST - aspartate aminotransferase

\section{DISCUSSION}

The prevalence of hypothyroidism in patients with NAFLD in our study was $15.5 \%$, higher than the worldwide prevalence in this context which ranges from $1 \%$ to $10 \%{ }^{(9,12,15 \text {, }}$ ${ }^{20)}$, and similar to previous studies in NAFLD patients ${ }^{(12)}$. In the general Brazilian population recent surveys are available only in high-risk populations, such as the elderly or women 
with cardiovascular complaints, with findings also lower, around $5 \%-7 \%{ }^{(1)}$.

There are several possible explanations for this high prevalence of hypothyroidism in NAFLD patients. The NAFLD is closely related to the metabolic syndrome (obesity, insulin resistance, impaired glucose metabolism, dyslipidemia and elevated blood pressure) ${ }^{(7)}$ and hypothyroidism in turn, can be linked to the components of this syndrome. Thyroid hormones can stimulate expression of uncoupling proteins in the mitochondria of fat and skeletal muscle, modulate adrenergic receptor numbers by enhancing responsiveness of catecholamines ${ }^{(13)}$, and thus control metabolic and energy homeostasis. They influence body weight, thermogenesis, lipolysis, and metabolism of cholesterol and bile acid. Hypothyroidism induces hyperlipidemia and obesity, and can lead to the development of gallstone disease and steatosis ${ }^{(14)}$. The mechanism of hypothyroidism induced hyperlipidemia resides in a decrease of cholesterol excretion and in a marked increase in apo B lipoproteins because of a decreased catabolism and turnover by a reduced number of low-density lipoprotein (LDL) receptors on the liver cell surface ${ }^{(4)}$. Thus a common finding in hypothyroidism patients is increased levels of total and LDL cholesterol. In hypothyroidism a reduced removal rate of triglyceride from plasma and an accumulation of intermediate low-density lipoprotein (IDL) have also been reported. Our study showed this correlation between triglycerides and NAFLD.

Besides hyperlipidemia and obesity, hypothyroidism also has been associated with insulin resistance ${ }^{(15)}$. There is a strong link between insulin resistance and excessive deposition of triglycerides in hepatocytes. A recent paper investigated the frequency of metabolic syndrome in hypothyroid patients. They studied 100 patients with overt hypothyroid, 100 patients with subclinical hypothyroid and 200 healthy controls. The authors found that HOMA index was higher in the hypothyroid group according to controls $(P=0.008)$ and subclinical hypothyroid group $(P=0.014)$. The metabolic syndrome prevalence was $44 \%$ in the hypothyroid group and $33 \%$ in the control group $(P=0.016)^{(5)}$. Our study could also correlate insulin resistance (measured by the HOMA index) in our patients with NAFLD and the presence of thyroid dysfunction, corroborating these data ${ }^{(5,15)}$.

In the present study, however, it was not possible to correlate the presence of hypothyroidism with NASH. At this point it is important to remember the mechanisms involved in the progression of fatty liver disease. Hepatic steatosis can progress to hepatocyte injury, inflammation and fibrosis from potential synergistic factors such as oxidative stress from $\beta$-oxidation, increased expression of inflammatory cytokines by NF-кB-dependent pathways and adipocytokines $(2,6,11)$. This is called the "multi-hit hypothesis" that has been used to describe the pathogenesis of NAFLD ${ }^{(8)}$. Lipid peroxidation and oxidative stress are believed to have an important role in the disease progression from steatosis to $\mathrm{NASH}^{(11,21)}$. There are some experimental data regarding thyroid dysfunction and hepatic lipid peroxidation, showing that in a state of hyperthyroidism, thyroid hormone elevation stimulates the metabolic rate possibly leading to reactive oxygen species generation, lipid peroxidation and liver cell damage ${ }^{(3,16)}$. On the other hand, the hypothyroidism state, with reduced levels of oxidative stress, might be responsible for the experimental finding that hypothyroidism protects from hepatic fibrosis ${ }^{(14)}$. This concept converges with the absence of correlation between hypothyroidism and steatosis or NASH observed in our work. In this study, mainly on obese NAFLD patients, hypothyroidism appears to contribute to the major components of metabolic syndrome, leading mainly to the accumulation of fat. However in the progression to NASH, additional insults seem to be needed, with emphasis on oxidative stress and lipid peroxidation. It is precisely in this aspect that hypothyroidism could act as a confounding factor and could halt the progression to NASH, justifying the lack of correlation found in our study.

\section{CONCLUSION}

A link could be affirmed between hypothyroidism and indexes of glucose homeostasis (HOMA, insulin), as well as with AST and triglycerides levels, all of which are closely related to NAFLD. However, a direct association between hypothyroidism and steatosis or NASH could not be demonstrated. This study also confirms the importance of searching for the diagnosis of hypothyroidism in patients with NAFLD, because of the high prevalence of thyroid dysfunction. These data taken together explain the recent interest in thyroid dysfunction and its relations with the metabolic syndrome and NASH. Further studies are needed to clarify the exact role of hypothyroidism in nonalcoholic fatty liver disease, and in its progression. 
Mazo DFC, Lima VMR, Stefano JT, Rabelo F, Faintuch J, Oliveira CP. Índices glicolipídicos no hipotireoidismo tratado associado à doença hepática gordurosa não-alcoólica. Arq Gastroenterol. 2011;48(3):186-9.

RESUMO - Contexto - Os hormônios tireoidianos podem interferir na regulação do metabolismo de lipídios e carboidratos e também na gravidade da doença hepática gordurosa não-alcoólica (DHGNA), porém os resultados ainda são debatidos. Objetivos - Avaliar retrospectivamente correlações clínicas e metabólicas entre hipotireoidismo e DHGNA. Métodos - Em 103 pacientes com DHGNA confirmada por biopsia e também hipotireoidismo recebendo tratamento, procedeu-se à investigação clínica, bioquímica e histológica. Resultados - A esteatose foi observada em 32,0\% e a esteatohepatite não-alcoólica em $68,0 \%$ da população. O sexo feminino foi mais frequente nas duas circunstâncias, com idade média de 50,0 $\pm 1,5$ e $56,0 \pm 1,1$ anos, respectivamente. O hipotireoidismo não foi raro $(15,5 \%)$, sendo que na análise multivariada insulina $(\mathrm{r}=0,213, P=0,03)$, índice de homeostase glicídica HOMA $(\mathrm{r}=0,221, P=0,02)$, aspartato aminotransferase $(\mathrm{r}=0,234, P=0,01)$ e triglicerídeos acima de $150 \mathrm{mg} / \mathrm{dL}(\mathrm{r}=0,233, P=0,01)$ foram correlacionados positivamente com hipotireoidismo. A associação entre hipotireoidismo e esteatohepatite não pôde ser estabelecida neste estudo. Conclusão - O hipotireoidismo vinculou-se à piora de alguns marcadores do metabolismo glicolipídico, porém não a lesões histológicas mais avançadas. A falta de correlação com a biopsia do fígado requer maiores estudos.

DESCRITORES - Glicolipídios. Fígado gorduroso. Hipotireoidismo.

\section{REFERENCES}

1. Benseñor IM, Goulart AC, Lotufo PA, Menezes PR, Scazufca M. Prevalence of thyroid disorders among older people: results from the São Paulo Ageing \& Health Study. Cad Saúde Pública. 2011;27:155-61.

2. Byrne CD, Olufadi R, Bruce KD, Cagampang FR, Ahmed MH. Metabolic disturbances in non-alcoholic fatty liver disease. Clin Sci (Lond). 2009;116: 539-64.

3. Das K, Chainy GB. Modulation of rat liver mitochondrial antioxidant defence system by thyroid hormone. Biochim Biophys Acta. 2001;1537:1-13

4. Duntas LH. Thyroid disease and lipids. Thyroid. 2002;12:287-93.

5. Erdogan M, Canataroglu A, Ganidagli S, Kulaksızoglu M. Metabolic syndrome prevelance in subclinic and overt hypothyroid patients and the relation among metabolic syndrome parameters. J Endocrinol Invest. 2010; Jul 22. [Epub ahead of print].

6. Farrell GC, Larter CZ. Nonalcoholic fatty liver disease: from steatosis to cirrhosis. Hepatology. 2006;43:S99-S112.

7. Grundy SM, Brewer HB Jr, Cleeman JI, Smith SC Jr, Lenfant C; American Heart Association, National Heart, Lung, and Blood Institute. Definition of metabolic syndrome: report of the National Heart, Lung, and Blood Institute/American Heart Association conference on scientific issues related to definition. Circulation. 2004; 109:433-8.

8. Jou J, Choi SS, Diehl AM. Mechanisms of disease progression in nonalcoholic fatty liver disease. Semin Liver Dis. 2008;28:370-9.

9. Khan U, Sowers JR. Cardiometabolic syndrome and thyroid dysfunction. J Cardiometab Syndr. 2007;2:81-3.

10. Kleiner DE, Brunt EM, Van Natta M, Behling C, Contos MJ, Cummings OW, Ferrell LD, Liu YC, Torbenson MS, Unalp-Arida A, Yeh M, McCullough AJ, Sanyal AJ; Nonalcoholic Steatohepatitis Clinical Research Network. Design and validation of a histological scoring system for nonalcoholic fatty liver disease. Hepatology. 2005;41:1313-21.

11. Lewis JR, Mohanty SR. Nonalcoholic fatty liver disease: a review and update. Dig Dis Sci. 2010;55:560-78.

12. Liangpunsakul $\mathrm{S}$, Chalasani $\mathrm{N}$. Is hypothyroidism a risk factor for non-alcoholic steatohepatitis? J Clin Gastroenterol. 2003;37:340-3.
13. Lin SY, Wang YY, Liu PH, Lai WA, Sheu WH. Lower serum free thyroxine levels are associated with metabolic syndrome in a Chinese population. Metabolism. 2005;54:1524-8.

14. Loria P, Carulli L, Bertolotti M, Lonardo A. Endocrine and liver interaction: the role of endocrine pathways in NASH. Nat Rev Gastroenterol Hepatol. 2009;6:236-47.

15. Maratou E, Hadjidakis DJ, Kollias A, Tsegka K, Peppa M, Alevizaki M, Mitrou P, Lambadiari V, Boutati E, Nikzas D, Tountas N, Economopoulos T, Raptis AS, Dimitriadis G. Studies of insulin resistance in patients with clinical and subclinical hypothyroidism. Eur J Endocrinol. 2009;160:785-90.

16. Messarah M, Boumendjel A, Chouabia A, Klibet F, Abdennour C, Boulakoud MS, Feki AE. Influence of thyroid dysfunction on liver lipid peroxidation and antioxidant status in experimental rats. Exp Toxicol Pathol. 2010;62:301-10.

17. National Cholesterol Education Program (NCEP), Expert Panel on Detection, Evaluation, and Treatment of High Blood Cholesterol in Adults (Adult Treatment Panel III). Third report of the National Cholesterol Education Program (NCEP) expert panel on detection, evaluation, and treatment of high blood cholesterol in adults (Adult Treatment Panel III): final report. Circulation. 2002;106:3143421.

18. Rector RS, Thyfault JP, Wei Y, Ibdah JA. Non-alcoholic fatty liver disease and the metabolic syndrome: an update. World J Gastroenterol. 2008;14:185-92.

19. Schindhelm RK, Diamant M, Dekker JM, Tushuizen ME, Teerlink T, Heine RJ. Alanine aminotransferase as a marker of non-alcoholic fatty liver disease in relation to type 2 diabetes mellitus and cardiovascular disease. Diabetes Metab Res Rev. 2006;22:437-43.

20. Shantha GP, Kumar AA, Jeyachandran V, Rajamanickam D, Rajkumar K, Salim S, Subramanian KK, Natesan S. Association between primary hypothyroidism and metabolic syndrome and the role of $\mathrm{C}$ reactive protein: a cross-sectional study from South India. Thyroid Res. 2009;2:2.

21. Tiniakos DG, Vos MB, Brunt EM. Nonalcoholic Fatty Liver Disease: Pathology and Pathogenesis. Annu. Rev. Pathol. Mech. Dis. 2010;5:145-71. 